\title{
Modelling the Rainfall Erosivity of the Rhone Region (Southeastern France) Associated with Climate Variability and Storminess
}

\author{
Nazzareno Diodato, ${ }^{1,2}$ Gianni Bellocchi, ${ }^{1,3}$ Nunzio Romano, ${ }^{4}$ and Francesco M. Guadagno ${ }^{2}$ \\ ${ }^{1}$ Met European Research Observatory, Via Monte Pino snc, 82100 Benevento, Italy \\ ${ }^{2}$ Department of Sciences and Technology, University of Sannio, Via Pont'Arsa 11, 82100 Benevento, Italy \\ ${ }^{3}$ Grassland Ecosystem Research Unit, French National Institute of Agricultural Research, 5 chemin de Beaulieu, \\ 63039 Clermont-Ferrand, France \\ ${ }^{4}$ Department of Agriculture, AFBE Division, University of Napoli Federico II, Via Università 100, 80138 Naples, Italy
}

Correspondence should be addressed to Nazzareno Diodato; scodalabdiodato@gmail.com

Received 2 June 2015; Revised 4 August 2015; Accepted 6 August 2015

Academic Editor: Sergio M. Vicente-Serrano

Copyright (c) 2016 Nazzareno Diodato et al. This is an open access article distributed under the Creative Commons Attribution License, which permits unrestricted use, distribution, and reproduction in any medium, provided the original work is properly cited.

\begin{abstract}
Changes in the spatial and temporal patterns of extreme rainfall may have important effects on the magnitude and timing of rainfall erosivity, which in turn lead to even severe soil degradation phenomena. The Mediterranean belt is characterized by strong climatic variability and specific seasonal features, where dry periods are often interrupted by pulsing storms. Identifying the thresholds associated with extreme rainfall events is among the most important challenges for this region. To discern the spatial patterns of rainfall erosivity hazard in the Rhone region (eastern France), this study establishes thresholds in the power of rainstorms. An indicator Kriging approach was employed for computing probability maps of the annual rainfall erosivity exceeding the threshold of $1800 \mathrm{MJ} \mathrm{mm} \mathrm{ha}{ }^{-1} \mathrm{~h}^{-1}$, the latter being twice greater than the standard deviation. The interdecadal spatial patterns of hazard were assessed for recent decades (1991-2010) and the precedents ones (1961-1990). Climate fluctuations of rainfall erosivity revealed possible signals of increased storminess hazard across the region in recent times. We also discussed changes in the rainfall erosivity hazard forcing as related to climatic changes in daily rain rate, especially in autumn when the erosivity is likely affected by more intense storminess occurring across the southern part of the Rhone region.
\end{abstract}

\section{Introduction}

Environmental systems are generally in a state of dynamic equilibrium with external driving forces [1]. However, the recurrence of extreme climate events such as storms and floods can accelerate soil loss (sediment transport) in regional catchments. In this context, the identification of enhanced interdecadal climate signals may demonstrate the existence and help understanding the role of abrupt environmental changes over relatively long time periods [2-5]. Understanding how climate forcing affects region-wide responses is crucial for the purpose of erosion and sediment modelling and the reconstruction of hydrogeomorphological hazards $[6,7]$. It also provides a new perspective to the study of landscape conservation and climate change, especially in highly dynamic systems (such as agricultural systems). Practical decision-making for protection from time-distributed extreme events often involves using environmental process models, also linked to temporal GIS (Geographical Information System). This is particularly true in subregional basins of Mediterranean Europe, which are characterised by hydrogeomorphological processes often dominated by extreme rainfall events and related rainfall erosivity, grouped in some particularly stormy years according to climate variability [711]. The maps of rainfall erosivity in Figure 1 give a spatial overview of the erosion risk in the Northern Hemisphere (Figure 1(a)), with focus on Europe (Figure 1(b)). The current availability of rainfall erosivity data worldwide provides a first 


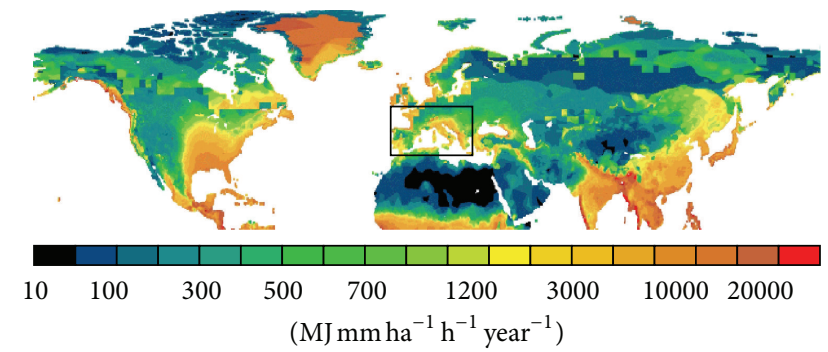

(a)

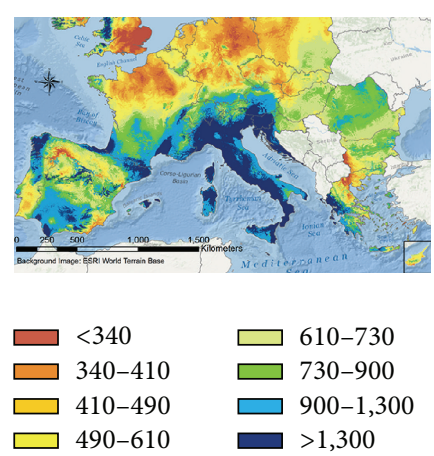

(b)

FIGURE 1: (a) Distribution of long-term mean of the rainfall erosivity (1961-1990) at five-arc-minute resolution (adapted from Naipal et al. [56]) for the Northern Hemisphere, (b) with detailed focus (0.1-arc-minute resolution) on Europe as arranged from European erosivity dataset for the period 2002-2011 [46].

and approximate basis for establishing which regions suffer most from rainfall erosivity and storminess, which requires further exploration and modelling at smaller spatial scales.

Societal infrastructures are becoming more sensitive to weather and climate extremes, which would be exacerbated by climate variability [12-14]. This has triggered a set of studies to determine the change in the probability of heavy precipitations at both global [12, 15, 16], and regional-subregional scales [17-20]. In spite of these efforts, still isolated researches are available documenting to which extent past storm-climatic variability has actually affected the dynamics of rainfall erosivity and landscape responses. Kundzewicz [21] prospected a greater variability of stormflow throughout the globe, both at seasonal and daily scales, coupled with an increase in the frequency of flash floods and rainfall erosivity, especially at mid- to high-latitudes.

The focus of this study is the Rhone river basin (RRB), in southeastern France [22]. This basin is particularly injured by erosivity and floods, which involve surface responses to precipitation events such as the relationship between rainfallrunoff responses and flood-routing mechanisms [23]. Heavy precipitation in the Rhone basin can be attributed to either convective or nonconvective processes or to a combination of them both $[24,25]$. Large amounts of precipitation can accumulate over several day-long periods when one or several frontal perturbations slow down and then are enhanced by the relief of the Massif Central and the Alps. The occurrence of exceptionally heavy rainfall events and associated floods and sediment and organic carbon fluxes in many European areas during recent decades [26, 27] motivated us to study long-term changes in the forcing of storm erosivity in the Rhone region. In mainland France, in particular, flash floods and accelerated soil erosion represent the most destructive natural hazards, having caused billions of Euros in damage over the last two decades [26]. Severe flooding events between 1993 and 2003 in the Rhone catchments of Switzerland and France also caused loss of life [28, 29]. In recent times, damaging hydrological events occurred in the Rhone basin showing a climatic shift towards more erratic spatial and temporal distribution of extreme rainfalls, in the form of large-scale pulsing storms [30]. The catastrophic flash flood event of 8-9 September 2002 in the Gardon gorge of France (Gardon river ends into the Rhone at Comps, 43.85 latitude north and 4.61 longitude east) was particularly remarkable for its spatial extent with rain amounts greater than $200 \mathrm{~mm}$ in 24 h over $5500 \mathrm{~km}^{2}$ [31].

This paper explores the feasibility to quantify the relative contribution of rainfall erosivity to the long-term annual and seasonal precipitations falling across the RRB. The major aim of the present study is to develop and evaluate an approach to (i) explain the interdecadal variability of rainfall erosivity and readily available climate data and (ii) recognize seasonal precipitations associated with different seasonal storm types. We hypothesized that the autumn rainfall pattern is an important component of the annual erosivity amount.

\section{Environmental Setting and Modelling}

2.1. Study Area. The Rhone river watershed covers a surface area of about $98000 \mathrm{~km}^{2}$, shared by France (92\%) and Switzerland. The Rhone river ( $813 \mathrm{~km}$ long) overpasses from north to south the Rhone region originating in the Swiss Alps (Rhone Glacier, $1765 \mathrm{~m}$ a.s.l.) and runs through southeastern France for $550 \mathrm{~km}$ before entering the Mediterranen Sea. The river is bordered by about 16 million people $(\sim 1.2$ million in Switzerland). With $\sim 20 \%$ of France's agriculture and industry and $~ 50 \%$ of France's tourism activity (after the Rhone-Mediterranean and Corsica Water Agency, through http://www.eaurmc.fr/), the area is identified as of prominent economic importance, the gross domestic product exceeding US\$ 52000 million in total [32]. Roughly $70 \%$ of the surface water withdrawn in the basin is used for agricultural purposes, while domestic use and industry both use about $15 \%$. Some other uses of the water are hydropower in the Alps, cooling French thermal and nuclear reactors, recreation, and navigation between Lyon (France) and the Mediterranen Sea [33]. The Rhone river contributes $69 \%$ of the total sediment export for France, whereas its drainage area represents only $23 \%$ of the total area [27]. The basin is placed in a core area with the highest 95th percentiles of June-November daily rainfalls in Europe [30]. The high yearly and seasonal 


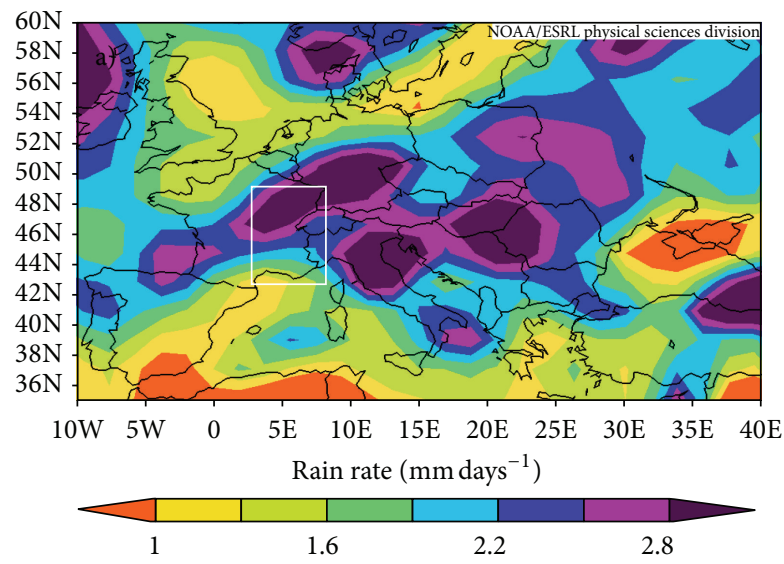

(a)

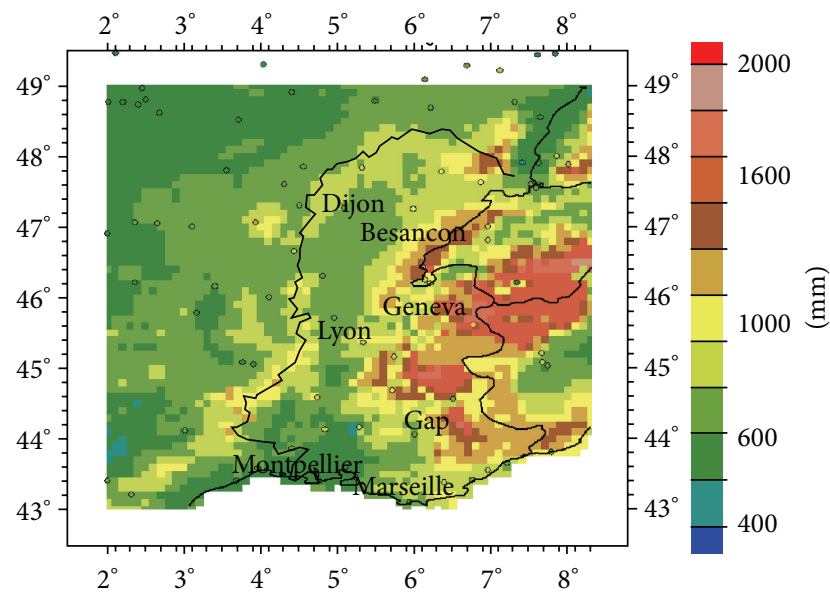

(b)

FIGURE 2: (a) Setting of the study area crossed by annual precipitation rates (1948-2014) via NOAA-ESRL NCEO Reanalysis, (b) with relative zoom of annual mean precipitation of Rhone region, as arranged from LocClim (http://www.fao.org/nr/climpag/pub/en0201_en.asp) via Inverse Distance Weighting with rainfall-elevation extrapolation.

variability of precipitation is mainly the result of the synoptic circulation that advects air masses of different origins (Mediterranean, maritime, polar maritime, and subtropical). However, most dynamic effects are modulated with more recurrence by the Mediterranean and Atlantic Sea. Air masses allow high storage of humidity representing the main energy supply for thunderstorms, which in turn are triggered by outbreaks of warm Mediterranean Sea and Atlantic maritime air in the middle troposphere [34].

The eastern areas and the mountains receive the highest annual precipitation amounts $(1400-2000 \mathrm{~mm}$ on average, Figure 2). Eastern areas have summer storms of continental influence, whereas cold winter temperatures occur in the Savona valley. The southern part of the Rhone region has a typical Mediterranean climate, with hot and dry summers and rainfall mostly occurring in spring and autumn. The total average annual precipitation has a value of approximately $600 \mathrm{~mm} \mathrm{yr}^{-1}$ in the north-south transect valley, but rainfall can become intense in September and October in the Cevennes Range (1600 $\mathrm{m}$ a.s.l.), located in the southeast of the basin. The maximum values of $600-700 \mathrm{~mm}$ observed on 89 September 2002 in the Gard gorge are among the highest daily records in the region [31].

2.2. Precipitation Hazard Types. Cyclones build up in three principal areas of the northern Mediterranean Basin: the Gulf of Genoa, the Aegean Sea, and the Black Sea. Generally, subsynoptic scale precipitation systems are produced and triggered by the passage of remnant north Atlantic synoptic fronts and their interaction with local topography [35]. However, the highest frequency on intense cyclones with maximum circulation exceeding $7 \times 10^{7} \mathrm{~m}^{2} \mathrm{~s}^{-1}$ and a liftime of a least $24 \mathrm{~h}$ occurred in the Mediterranean area, with the core across central Italy [36]. These circulation types are characterized by warm and cold air sequences, with rainfall conditions mainly depending on evolving air mass. Other factors determining rainfall conditions are the wind direction at $500 \mathrm{hPa}$, the trajectory of the low pressure system, the orography, the distance from the sea of each specific area of interest, and surface roughness [37]. Their impact on rainfall is related to the intensity of the cold air intrusion, as well as to the depth of the associated sub-low-pressure system. The most hazardous precipitation events can occur associated with these subsynoptic scale systems. They include flash floods and floods that may have, however, different seasonal regimes (Figures 3(a) and 3(b)).

The period of occurrence of flood situations (especially those driven by convective rainfalls) may serve to identify periods during which extreme rainfall amounts occur. For the area of interest, the flash floods show a bimodal summer-late autumn distribution (one peak is usually noted in July and a second peak in October [38]), while floods have a typical autumn regime. The interweaving of these hydrological regimes is important because they are driven by the rainfall erosivity types that play a fundamental role in determining the intensity of these damaging floods phenomena. On the other hand, they may be useful for reconstructing rainfall erosivity in the past, when no detailed records of rainfall data are available.

Floods are common in the RRB and are known as "extraordinary flooding" or intermediate floods which, for their disruption activity, are particularly hazardous events [31]. Intermediate floods are events with duration of less than 24 hours and the maximum precipitation is usually recorded in less than six hours, with accumulated rainfall usually greater than $200 \mathrm{~mm}$ [39].

2.3. Experimental Data in Rainfall Erosivity. In order to evaluate storminess in both spatial and temporal domains and to provide evidence of a likely correspondence between trends in storminess and extreme rainfall, the rainfall erosivity factor is computed for decadal and longer periods, based 


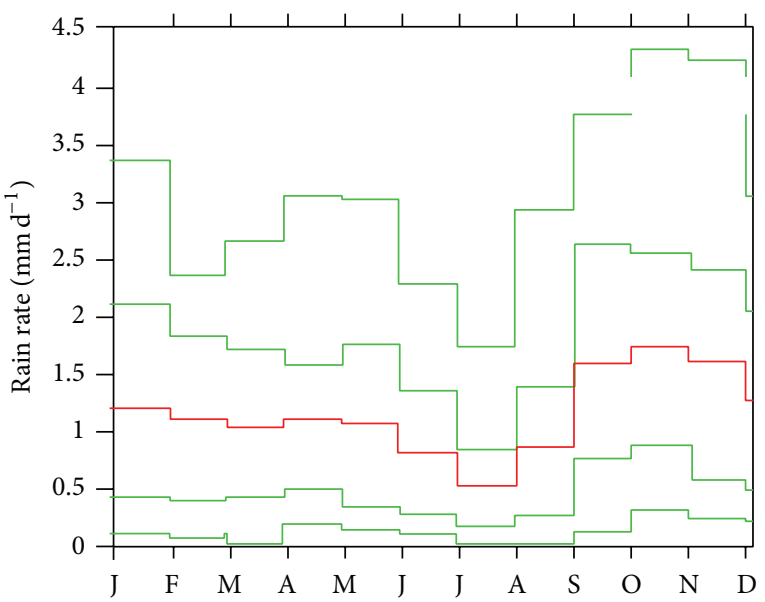

(a)

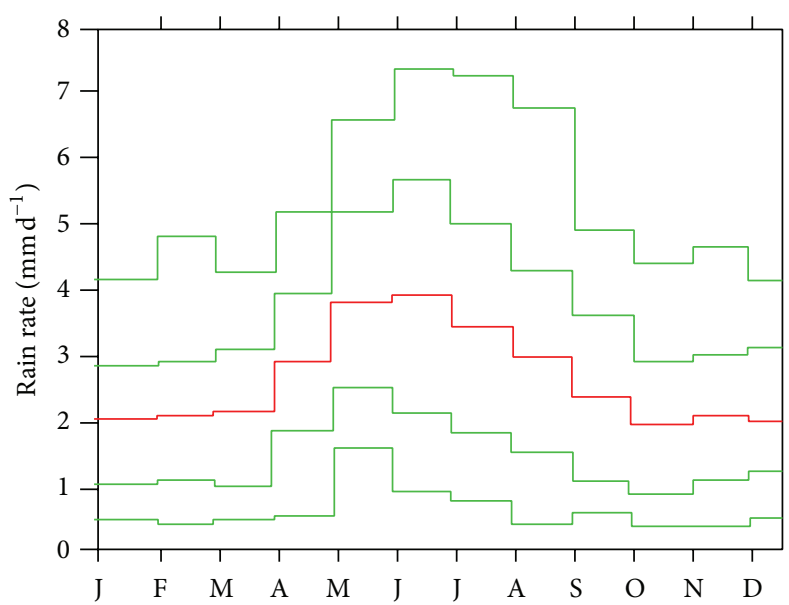

(b)

Figure 3: Mean monthly rain rates (red line) with the 25th and the 95th percentile (green lines) for (a) lower and (b) upper Rhone river basin (data arranged from NCEP Reanalysis provided via KNMI-Climate Explorer for the period 1961-2010 [57]).

on concepts by Diodato and Bellocchi [40], who derived the following relation for France [41]:

$$
R_{\mathrm{DREMM}}=\alpha \cdot \sqrt{P_{(\max ) \mathrm{Oct}}}+\left(P_{\mathrm{prc} 95(\mathrm{M}-\mathrm{O})}\right)^{\eta},
$$

where $R_{\text {DREMM }}\left(\mathrm{MJ} \mathrm{mm} \mathrm{ha} \mathrm{m}^{-1} \mathrm{~h}^{-1} \mathrm{y}^{-1}\right.$ ) is the estimated longterrm (10-year or longer periods) mean rainfall erosivity, $P_{\text {prc95(M-O) }}(\mathrm{mm})$ is the 95 th percentile of the monthly rainfall from May $(\mathrm{M})$ to October $(\mathrm{O})$ over each decade, $P_{(\max ) \text { Oct }}$ $(\mathrm{mm})$ is the maximum monthly rainfall in October over the decade, $\alpha$ is a scale parameter, and $\eta=2.459-0.02266$. Lat -0.004777 . Long (where Lat and Long are latitude and longitude in degrees, taken at the centre of each grid point).

To estimate rainfall erosivity, 100 rainfall grid points covering the studied area were generated (using Kriging interpolation via ESRI-ArcGIS Geostatistical Analyst Extension [42]) based on the GPCC V6 Monthly LandSurface Precipitation from Rain-Gauges, built on GTS-based and Historic Data with resolution of $0.5^{\circ}$ [33] and supplied by Climate Research Unit at the University of East Anglia, United Kingdom (http://badc.nerc.ac.uk/data/cru).

2.4. Exceedance Probability Maps of Rainfall Erosivity. The nonparametric ordinary Kriging method known as indicator Kriging [43] was used to compute the probability maps of the annual rainfall erosivity being greater than a threshold. Compared to parametric approaches, indicator Kriging has the advantage of being less affected by the presence of outliers. The ordinary indicator Kriging (OIK) estimator for the rainfall erosivity is a linear combination of $i\left(s_{\alpha} ; z_{k}\right)$ observations in the neighbourhood $s_{o}$ :

$$
\begin{gathered}
{\left[\operatorname{Prob}\left(Z\left(s_{o}\right)>z_{k} \mid(n)\right)\right]_{\mathrm{OIK}}{ }^{*}} \\
\quad=\sum_{\alpha=1}^{n} \lambda_{\alpha, k}\left(s_{o} ; z_{k}\right) \cdot i\left(s_{\alpha} ; z_{k}\right),
\end{gathered}
$$

where $\lambda_{\alpha}$ are weighting factors calculated by solving the Kriging simultaneous equation system [40]. In order to assess changes in the rainfall forcing as related to climate changes, the probability maps of mean annual rainfall erosivity discussed in this study were generated for the periods 19611990 and 1991-2010 and assembled using ArcGIS platform 9.1 release of the ESRI (http://www.esri.com/software/arcgis).

\section{Results and Discussion}

3.1. Model Assumptions and Evaluation. In (1), monthly rainfall quantiles and the geographical control are modelled together to account for temporal and spatial dependencies of rainfall erosivity. Equation (1) is subject to the assumption that a large quantile value (95th percentile) of the monthly precipitation distribution over one or more decades is capable of delivering high values of rainfall erosivity, causative of extreme hydrological events. In this way, cumulated occurrence and magnitude of these events per decade(s) are controlled by the combination of climatic and hydrologic factors that the modelled $R$-factor helps to reveal. This is in agreement with the results referred by Hydrate database [26], which revealed the predominant role played by rainfall erosivity in explaining extreme events (Figure 4(b)). Based on this understanding, in (1) captures extreme rainfall events by percentiles statistics across the months from May to October, representing rainfall erosivity through a power-law function with an exponent $(\eta)$ varying geographically. The scale parameter $\alpha=24$ is a conversion factor that can be conveniently assumed constant over time and space. Its value is the same as that estimated at continental scale [40], which was used as initial value and did not change over the calibration process. The varying exponent not only provides a parsimonious description but also is a generic mechanism of the process that serves to either attenuate or enhance rainfall erosivity depending on site-specific climate conditions. In general, geographic location is known to be an important 


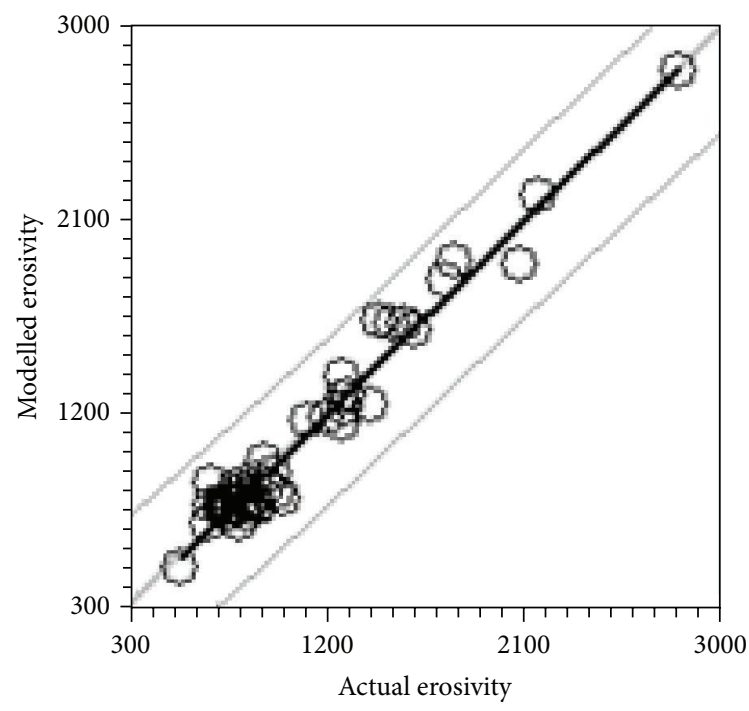

(a)

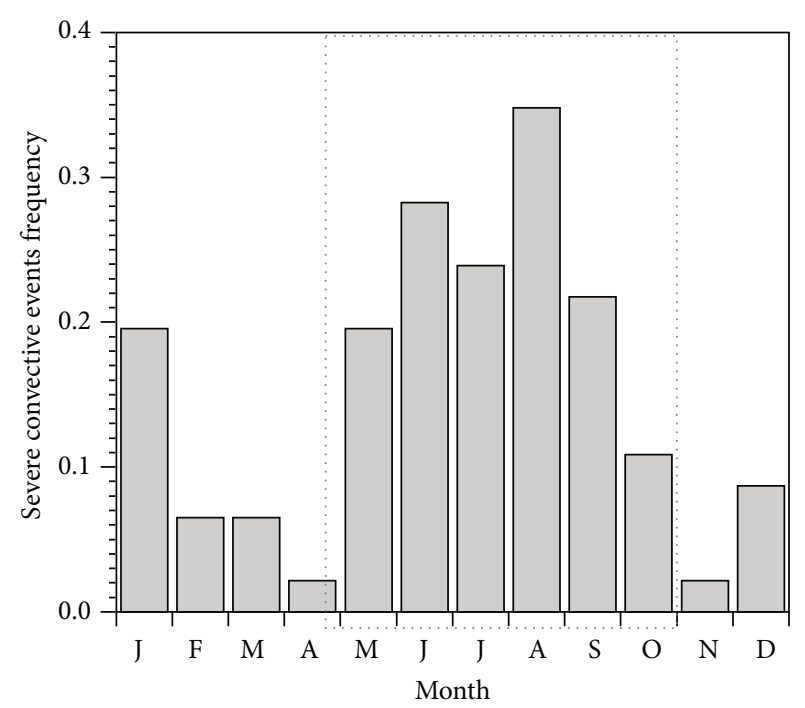

(b)

FIgURE 4: (a) Scatterplot between modelled (equation (1)) and actual ((R)USLE)-based rainfall erosivity. The black line is the interpolating line; the bold grey line denotes the 1:1 line; grey curves are 0.99 confidence limits of the interpolating line. (b) Monthly regime of severe convective events frequency estimated over 1957-2002 in Europe [58].

input property for rainfall erosivity models because the location, and then the climate zone, accommodates a broad range of conditions related to the occurrence of abundant and intense precipitation (e.g., [44]). We assumed that the exponent $\eta$ may continuously vary with latitude and longitude, as a shape term to modulate the percentile statistic that pulls out seasonal rainfall erosivity between May and October. In the warm season, in fact, cumulonimbus can be accompanied by high rain variability and intensity, thus releasing a large amount of energy through sparse or localized short phenomena, generally with duration of 0.5 to 3 hours [45]. Considering the relatively low temporal resolution of the model (decadal and multidecadal timescales), adjusting the rainfall erosivity response for changes in elevation was not used in (1).

The performance of (1) was assessed against actual $((R)$ USLE)-based rainfall erosivity data from a set of sites and periods in mainland France [41]: Bennwihr (48.15 N, 7.32 E), 1966-1994; Brive-la-Gaillarde (45.15 N, 1.53 E), 19511970; Clermont-Ferrand (45.80 N, 3.10 E), 1951-1970; Dijon (47.30 N, 5.10 E), 1951-1970; Gap (44.57 N, 6.07), 19511970; Horbourg-Wihr (48.10 N, 7.40 E), 1951-1970; Hunspach (48.95 N, 7.95 E), 1976-1994; Montpellier (43.60 N., 3.90 E), 1961-1990; Orléans (47.90 N, 1.90 E), 1951-1970; Paris (48.80 N, 2.50 E), 1951-1970; Rennes (48.10 N, 1.69 W), 1951-1970; Rouen (49.40 N., 1.20 E), 1959-1988; Stenay (49.50 N, 5.20 E), 1950-2000; Toulouse (44.80 N, 0.70 W), 1951-1970; Valence $(44.95 \mathrm{~N}, 4.90 \mathrm{E}), 1951-1970$. Overall, the mean absolute error was $91 \mathrm{MJ} \mathrm{mm} \mathrm{ha} \mathrm{m}^{-1} \mathrm{~h}^{-1} \mathrm{y}^{-1}$, the modelling efficiency was equal to 0.98 , and the regression line was in close proximity to the identity line (Figure 4(a)).

3.2. Temporal Analysis of Rainfall Erosivity with GIS. For the southwestern part of the basin (between Lyon and Montpellier) and for the period 1961-1990, Figure 5(a) shows the map of rainfall erosivity exceeding the threshold value of $1800 \mathrm{MJ} \mathrm{mm} \mathrm{h} \mathrm{ha}^{-1} \mathrm{y}^{-1}$. The threshold $1800 \mathrm{MJ} \mathrm{mm} \mathrm{h}{ }^{-1} \mathrm{ha}^{-1} \mathrm{y}^{-1}$ was based upon two standard deviations added to the mean. This threshold does not reflect the maximum values of the rainfall erosivity found in some European stations (exceeding 2000 up to $>6000 \mathrm{MJ} \mathrm{mm} \mathrm{h}^{-1} \mathrm{ha}^{-1} \mathrm{y}^{-1}$ [46]) but is above the threshold values considered in previous studies (e.g., 1000 and $1500 \mathrm{MJ} \mathrm{mm} \mathrm{h}{ }^{-1} \mathrm{ha}^{-1} \mathrm{y}^{-1}$ [47]). When the period 1991-2010 was examined, erosivity exceeding $1800 \mathrm{MJ} \mathrm{mm} \mathrm{h}^{-1} \mathrm{ha}^{-1} \mathrm{y}^{-1}$ extended until the eastern limits of the basin, the northern part not being affected (Figure 5(b)).

These phases generated an erosivity band crossing large southern lands of the Rhone region, plus main rainfall aggressiveness cells, among Aosta (Italy), Sion, and Geneva (Switzerland).

During the most recent phase of warming (1991-2010), new hydrological processes kicked off further power northwards, from the Mediterranean coast towards the inland areas. This suggests pulsing of extreme rainfall events that occurred over parts of the region. As shown in the work by Diodato et al. [48], an increase in extreme rainfall events in the Mediterranean region drives changes in rainfall erosivity and, in turn, an increased hazard in soil erosion and flash flooding usually more often occurring in relatively smaller catchments. These storminess and rainfall extremes are common in the fall season when they produce floods and flash floods, with the same regime as recorded by the FLASH European database [27].

3.3. Seasonal Hazard and Extreme Rainfall Events. To detect whether the rainfall power expands across the Rhone region depending on a particular season, we analysed the 95th 


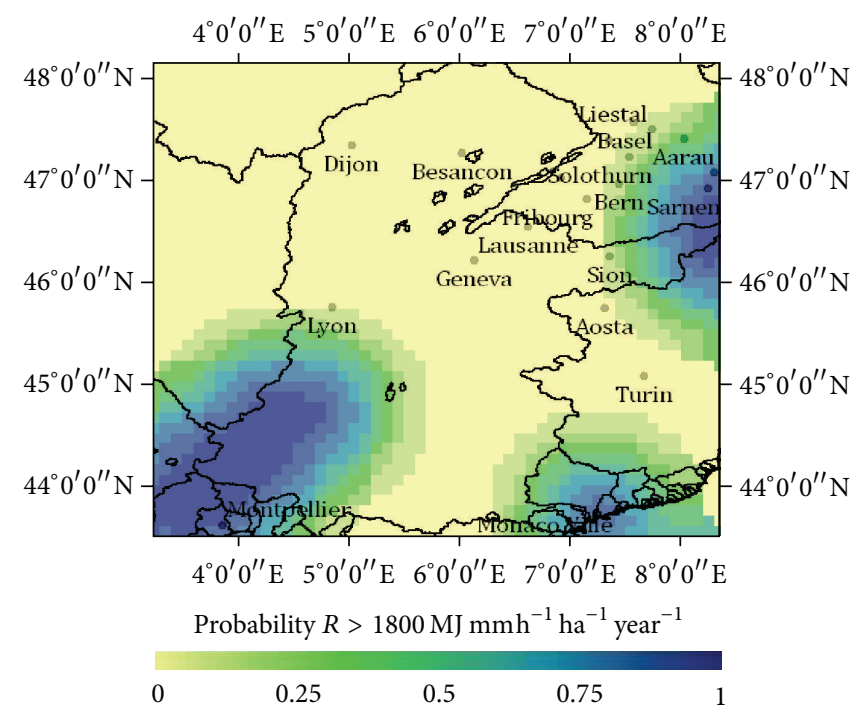

(a)

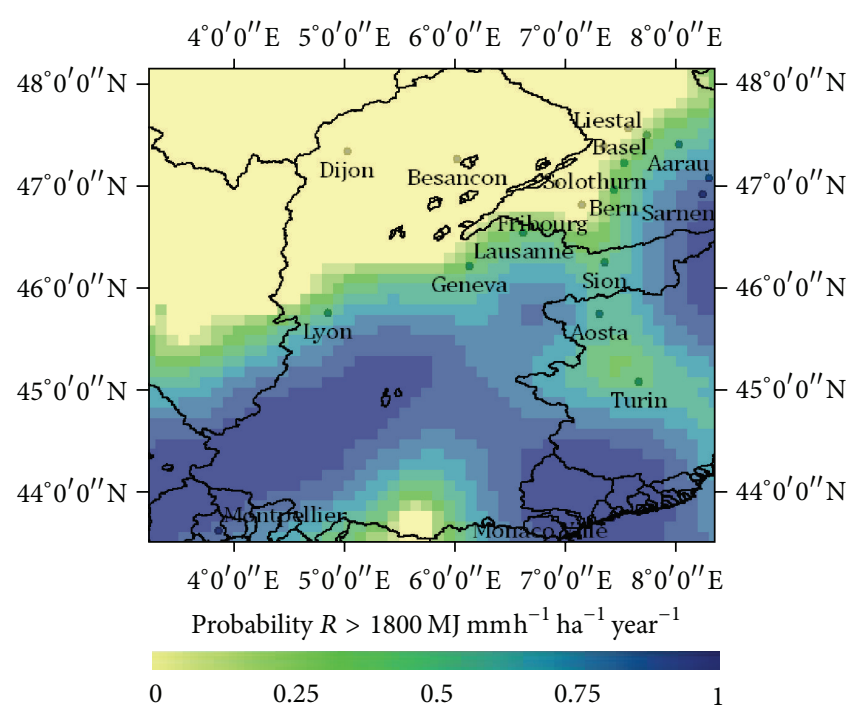

(b)

FIGURE 5: Indicator Kriging maps with probability that rainfall erosivity $(R)$ exceeds $1800 \mathrm{MJ} \mathrm{mm} \mathrm{h}^{-1} \mathrm{ha}^{-1} \mathrm{y}^{-1}$, for the periods $1961-1990$ (a) and $1991-2010$ (b).

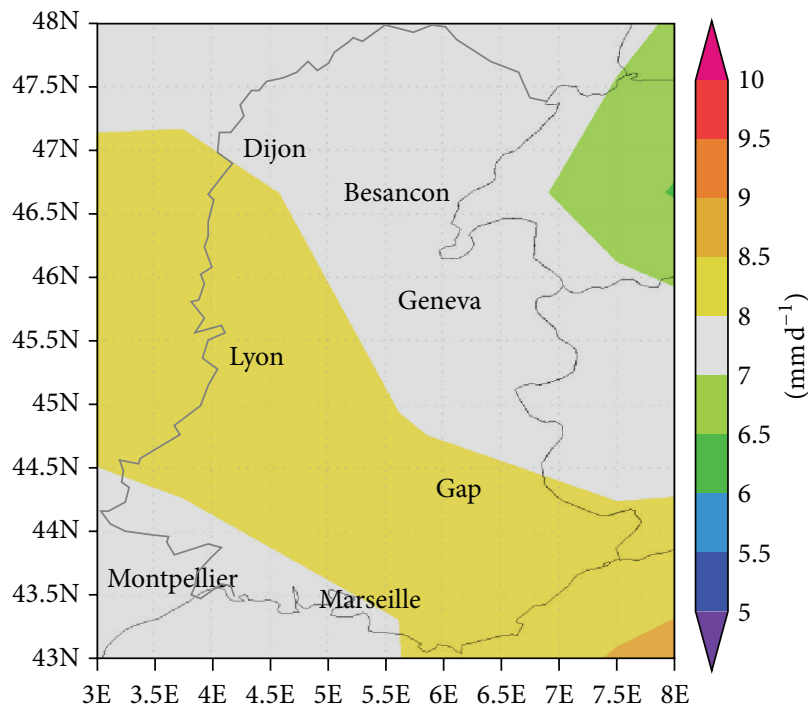

(a)

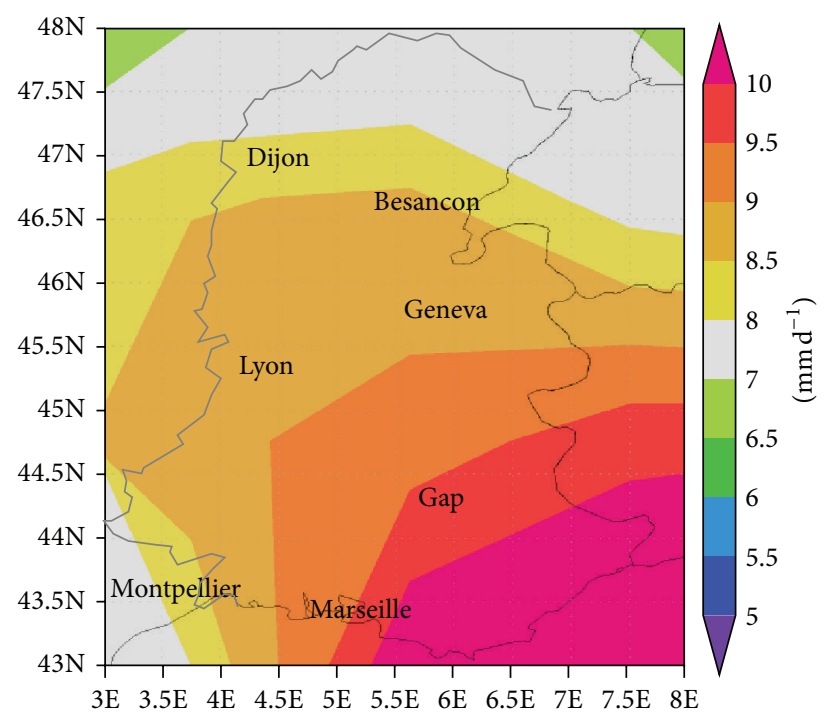

(b)

FIGURE 6: Spatial pattern of autumn daily rain rate 95th percentile across Rhone region for the periods 1951-1990 (a) and 1991-2013 (b). Data were arranged from NCEP/NCAR Reanalysis via Climate Explorer [57].

percentile of daily rain rate data from NCEP Reanalysis. It is therefore evident that autumn was the season with the highest rate of increase in the daily rainfall percentiles. This situation is clearly depicted in Figure 6 that compares the recent decades (1991-2013, Figure 6(b)) with the baseline climatology of the period 1951-1990 (Figure 6(a)). A remarkable increase in extreme rain rates in the past decades across the same area where rainfall erosivity was enhanced is worth noting (see Figure 5(b)).

Typically, the erosivity associated with the intensification of rain rates is the result of precipitations in the form of localized rainstorms (yet torrential), which are more frequent in summer and autumn. However, wet spring also brings additional runoff from rainfall but also provides antecedent conditions for summer flooding. In this case, not only heavy precipitation events but also moderate rain depths are of interest, because they provide favourable conditions (typical of local-scale storms) for floods occurring in heat period (June-October). For instance, the Cévennes-Vivarais region in the westernmost parts of the Rhone basin (on the border with the beginning of the Massif Central) has been especially affected by storms that caused floods on October 1995 [31]. 


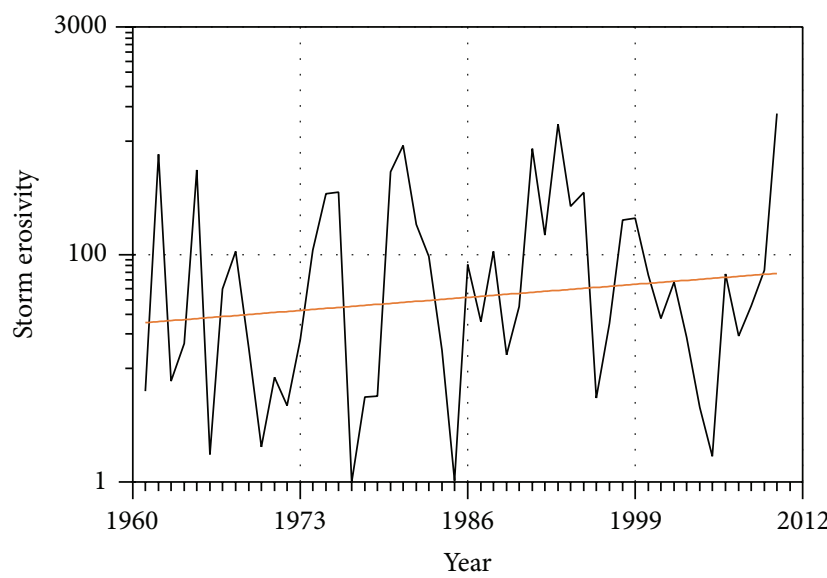

(a)

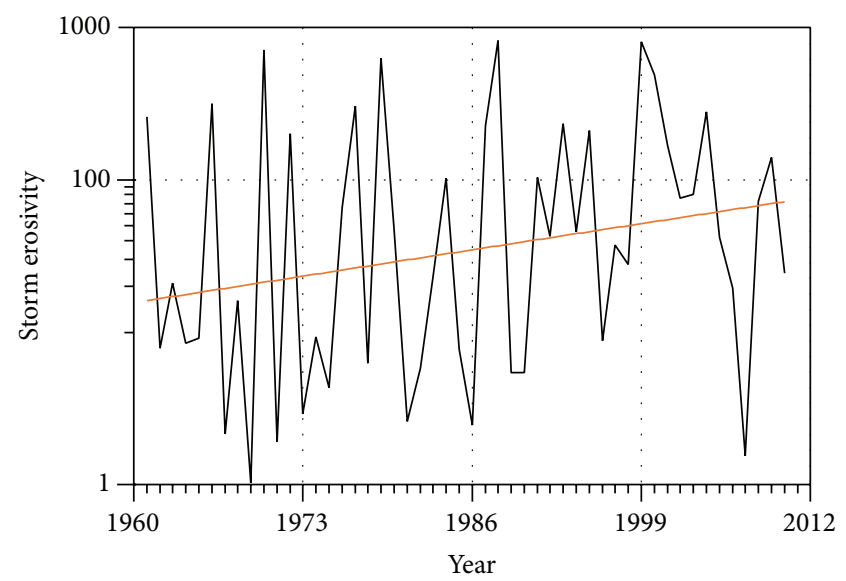

(b)

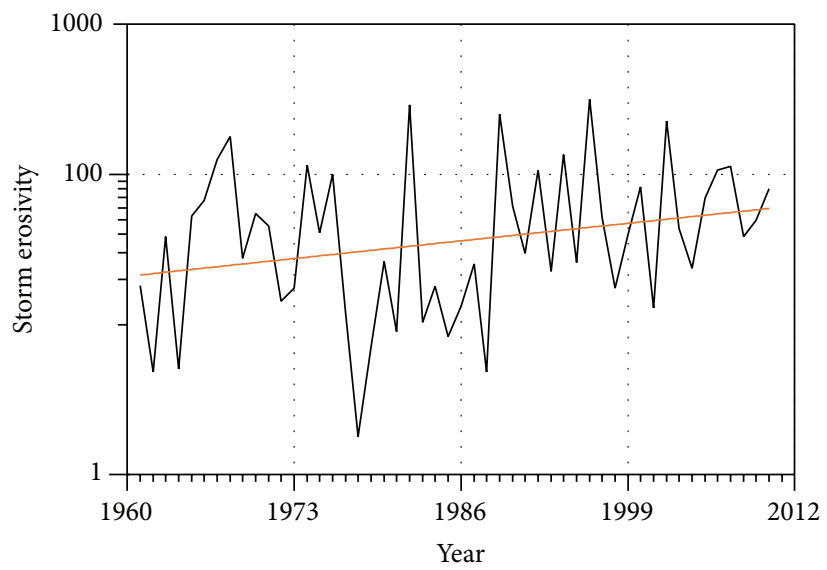

(c)

FIGURE 7: Temporal pattern of monthly storm erosivity at Lyon station for the months of September (a), October (b), and November (c) over the period 1961-2010, estimated with the model of Diodato [59]. Power trend with orange lines is also overlapped.

In the Aude (between the Massif Central and the eastern Pyrenees), during the flood event of 12-13 November 1999, the area receiving more than $200 \mathrm{~mm}$ in 48 hours extended more than $150 \mathrm{~km}$ in length and about $50 \mathrm{~km}$ in width [49]. The Gard precipitation event (8-9 September 2002) was an exceptional one due to the intensity of the event, with maximum precipitation around $600-700 \mathrm{~mm}$ in 24 hours (from 1200 UTC on 8 September) near Alès $[49,50]$. This event released more than $7000 \mathrm{MJ} \mathrm{mm} \mathrm{h}^{-1} \mathrm{ha}^{-1} \mathrm{~d}^{-1}$ energy (i.e., three times more than in one mean year). These results show that sediment exports depend not only on the water flows but also on specific environmental factors [51, 52]: evidently, the Mediterranean climate with severe but short storms in summer and autumn leads to more significant peaks in sediment flux compared with the temperate oceanic climate basins where rainfall events are generally characterized by a lower intensity and a longer duration.

It was also estimated that the material flood damage recorded in the European continent in 2002 had been higher than in any single year before [21]. At the beginning of December 2003, one of the biggest floods over at least the previous 150 yrs. was recorded in the Rhone river [53]. This extreme rainfall event resulted in one of the century's most significant floods in the Aude region and produced remarkable flash floods in some catchments. Amongst them, small ungauged catchments are recognized as the most vulnerable to storms driven by high daily rain intensity [54].

In the months of September, October, and November, flash floods are expected to increase around Lyon, where storm erosivity is rising (Figures 7(a), 7(b), and 7(c)). September and November, however, present an increase in peaks too, whereas October is affected by a more complex temporal pattern (for this month, only mean values are reported to increase). From these results, it emerges that storminess has been increasing in the recent warming period as caused by more frequent intensive autumnal storms. This is in line with the findings of Meusburger et al. [55] in Switzerland, where in recent times the monthly rainfall erosivity has been significantly increasing in the months between May to October.

\section{Conclusions}

Hydrological forcing and climate processes are known to lead to complex responses in river basins. For the Rhone basin, characteristic of French Mediterranean and Alpine 
environments, this work has analyzed a rainfall erosivity simulation as obtained with mesoscale indicator geostatisticsbased empirical model. This was done in an attempt to understand the sensitivity of the basin response (rainfall erosivity) to storminess (disturbing force) and to detect its temporal variability. The model allowed assessing erosivity changes at interdecadal time scales and revealed that the longterm trend is increasing. Since increased rainfall variability in response to climate change is a possibility in many regions, the effects of potential changes need to be addressed in the perspective of adapting to climate change. This is of considerable interest at present as the need to assess the impact of real or perceived climate change is vital in order to take correct environmental actions.

\section{Conflict of Interests}

The authors declare that there is no conflict of interests regarding the publication of this paper.

\section{References}

[1] C. Kosmas, M. Kirkby, and N. Geeson, The Medalus Project: Mediterranean Desertification and Land Use, European Union, Brussels, Belgium, 1999.

[2] H. A. Viles and A. S. Goudie, "Interannual, decadal and multidecadal scale climatic variability and geomorphology," Earth-Science Reviews, vol. 61, no. 1-2, pp. 105-131, 2003.

[3] N. Diodato, M. Ceccarelli, and G. Bellocchi, "Decadal and century-long changes in the reconstruction of erosive rainfall anomalies in a mediterranean fluvial basin," Earth Surface Processes and Landforms, vol. 33, no. 13, pp. 2078-2093, 2008.

[4] T. Swierczynski, A. Brauer, and S. Lauterbach, "A $1600 \mathrm{yr}$ seasonally resolved record of decadal-scale flood variability from the Austrian Pre-Alps," Geology, vol. 40, pp. 1047-1050, 2012.

[5] B.-T. Pan, H.-P. Geng, X.-F. Hu, R.-H. Sun, and C. Wang, "The topographic controls on the decadal-scale erosion rates in Qilian Shan Mountains, N.W. China," Earth and Planetary Science Letters, vol. 292, no. 1-2, pp. 148-157, 2010.

[6] M. A. Palecki, J. R. Angel, and S. E. Hollinger, "Storm precipitation in the United States. Part I. Meteorological characteristics," Journal of Applied Meteorology, vol. 44, no. 6, pp. 933-946, 2005.

[7] M. Mulligan, "Modelling the geomorphological impact of climatic variability and extreme events in a semi-arid environment," Geomorphology, vol. 24, no. 1, pp. 59-78, 1998.

[8] J. M. Hooke and J. M. Mant, "Geomorphological impacts of a flood event on ephemeral channels in SE Spain," Geomorphology, vol. 34, no. 3-4, pp. 163-180, 2000.

[9] P. D’Odorico, J. Yoo, and T. M. Over, “An assessment of ENSOinduced patterns of rainfall erosivity in the Southwestern United States," Journal of Climate, vol. 14, no. 21, pp. 4230-4242, 2001.

[10] R. Coppus and A. C. Imeson, "Extreme events controlling erosion and sediment transport in a semi-arid sub-Andean valley," Earth Surface Processes and Landforms, vol. 27, no. 13, pp. 1365-1375, 2002.

[11] M. C. Ramos and M. Mulligan, "Impacts of climate variability and extreme events on soil hydrological processes," Geophysical Research, vol. 5, pp. 92-115, 2003.
[12] D. R. Easterling, G. A. Meehl, C. Parmesan, S. A. Changnon, T. R. Karl, and L. O. Mearns, "Climate extremes: observations, modeling, and impacts," Science, vol. 289, no. 5487, pp. 20682074, 2000.

[13] K. E. Trenberth, A. Dai, R. M. Rasmussen, and D. B. Parsons, "The changing character of precipitation," Bulletin of the American Meteorological Society, vol. 84, no. 9, pp. 1205-1161, 2003.

[14] J. P. Nunes and M. A. Nearing, "Modelling impacts of climatic change," in Handbook of Erosion Modelling, pp. 289-312, WileyBlackwell, Oxford, UK, 2011.

[15] R. G. Jones, M. Noguer, D. C. Hassell et al., Generating High Resolution Climate Change Scenarios Using PRECIS, Met Office Hadley Centre, Exeter, UK, 2004.

[16] S. Curtis, T. W. Crawford, and S. A. Lecce, "A comparison of TRMM to other basin-scale estimates of rainfall during the 1999 Hurricane Floyd flood," Natural Hazards, vol. 43, no. 2, pp. 187198, 2007.

[17] P. Zhai, X. Zhang, H. Wan, and X. Pan, "Trends in total precipitation and frequency of daily precipitation extremes over China," Journal of Climate, vol. 18, no. 7, pp. 1096-1108, 2005.

[18] S. Beguería and S. M. Vicente-Serrano, "Mapping the hazard of extreme rainfall by peaks-over-threshold extreme value analysis and spatial regression techniques," Journal of Applied Meteorology and Climatology, vol. 45, no. 1, pp. 108-124, 2006.

[19] S. K. Aryal, B. C. Bate, E. P. Campbell, Y. Li, M. J. Palmer, and N. R. Viney, "Characterizing and modeling temporal and spatial trends in rainfall extremes," Journal of Hydrometeorology, vol. 10, no. 1, pp. 241-253, 2009.

[20] E. J. Becker, E. H. Berbery, and R. W. Higgins, "Understanding the characteristics of daily precipitation over the United States using the north American regional reanalysis," Journal of Climate, vol. 22, no. 23, pp. 6268-6286, 2009.

[21] Z. W. Kundzewicz, "Is the frequency and intensity of flooding changing in Europe?" in Extreme Weather Events and Public Health Responses, pp. 25-32, Springer, Berlin, Germany, 2005.

[22] J.-M. Olivier, G. Carrel, N. Lamouroux et al., "The Rhône river basin," in Rivers of Europe, pp. 247-296, Academic Press, London, UK, 2009.

[23] S. M. Jessup and A. T. DeGaetano, "A statistical comparison of the properties of flash flooding and nonflooding precipitation events in portions of New York and Pennsylvania," Weather and Forecasting, vol. 23, no. 1, pp. 114-130, 2008.

[24] S. Anquetin, F. Miniscloux, J. D. Creutin, S. Cosma, and S. Anquetin, "Numerical simulation of orographic rain," Journal of Geophysical Research, vol. 108, p. 8386, 2003.

[25] V. Ducrocq, D. Ricard, J.-P. Lafore, and F. Orain, "Stormscale numerical rainfall prediction for five precipitating events over France-on the importance of the initial humidity field," Weather and Forecasting, vol. 17, no. 6, pp. 1236-1256, 2002.

[26] E. Gaume, V. Bain, P. Bernardara et al., "A compilation of data on European flash floods," Journal of Hydrology, vol. 367, no. 1-2, pp. 70-78, 2009.

[27] M. C. Llasat, M. Llasat-Botija, M. A. Prat et al., "High-impact floods and flash floods in Mediterranean countries: the FLASH preliminary database," Advances in Geosciences, vol. 23, pp. 47$55,2010$.

[28] J.-P. Bravard, "Impacts of climate change on the management of upland waters: the Rhone river case," in Proceedings of the 5th Biennial Rosenberg International Forum on Water Policy, Banff, Canada, September 2006. 
[29] G. Arnaud-Fassetta, L. Astrade, E. Bardou et al., "Fluvial geomorphology and flood-risk management," Géomorphologie: Relief, Processus, Environnement, vol. 2, pp. 109-128, 2009.

[30] N. Diodato and G. Bellocchi, "Multiscale modelling of rainstorm-induced historical intermediate floods (JuneNovember) in the Rhone River Basin," Natural Hazards, vol. 65, no. 3, pp. 1465-1479, 2013.

[31] G. Delrieu, V. Ducrocq, E. Gaume et al., "The catastrophic flashflood event of 8-9 September 2002 in the Gard Region, France: a first case study for the Cévennes-Vivarais Mediterranean hydrometeorological observatory," Journal of Hydrometeorology, vol. 6, no. 1, pp. 34-52, 2005.

[32] K. Tockner, V. Bremerich, and I. Jentschke, "European map of the spatial extent and environmental state of riverine floodplains and deltaic areas," in Deliverable 4.14 of the EU-FP7 Project REFRESH-Adaptive Strategies to Mitigate the Impacts of Climate Change on European Freshwater Ecosystems, 2014, http://www.refresh.ucl.ac.uk/webfm_send/2410.

[33] A. Houston, “The Rhone river region," Transboundary Waters, 2012, http://www.caee.utexas.edu/prof/mckinney/ce397/Topics/ Rhone/Rhone\%282012\%29.pdf.

[34] J. Parajka, S. Kohnová, G. Bálint et al., "Seasonal characteristics of flood regimes across the Alpine-Carpathian range," Journal of Hydrology, vol. 394, no. 1-2, pp. 78-89, 2010.

[35] A. E. Harding, J. Palutikof, and T. Holt, "The climate system," in The physical geography of the Mediterranean, pp. 69-88, Oxford University Press, Oxford, UK, 2009.

[36] V. Homar, A. Jansà, J. Campins, A. Genovês, and C. Ramis, "Towards a systematic climatology of sensitivities of Mediterranean high impact weather: a contribution based on intense cyclones," Natural Hazards and Earth System Science, vol. 7, no. 4, pp. 445-454, 2007.

[37] K. Tolika, P. Maheras, M. Vafiadis, H. A. Flocas, and A. ArseniPapadimitriou, "Simulation of seasonal precipitation and raindays over Greece: a statistical downscaling technique based on artificial neural networks (ANNs)," International Journal of Climatology, vol. 27, no. 7, pp. 861-881, 2007.

[38] G. Bellocchi and N. Diodato, "Storm-erosivity model for addressing hydrological effectiveness in France," in Storminess and Environmental Change, vol. 39 of Advances in Natural and Technological Hazards Research, pp. 131-147, Springer, Dordrecht, The Netherlands, 2014.

[39] A. Barrera, M. Barriendos, and M. C. Llasat, "Extreme flash floods in Barcelona County," Advances in Geosciences, vol. 2, pp. 111-116, 2005.

[40] N. Diodato and G. Bellocchi, "Decadal modelling of rainfallrunoff erosivity in the Euro-Mediterranean region using extreme precipitation indices," Global and Planetary Change, vol. 86-87, pp. 79-91, 2012.

[41] G. Bellocchi and N. Diodato, "Storm-erosivity model for addressing hydrological effectiveness in France," in Storminess and Environmental Change, pp. 131-147, Springer, Dordrecht, The Netherlands, 2014.

[42] K. Johnston, J. M. Ver Hoef, K. Krivoruchko, and N. Lucas, Using ArcGis Geostatistical Analyst, ESRI, New York, NY, USA, 2001.

[43] C. V. Deutsch and A. G. Journel, GSLIB: Geostatistical Software Library and User's Guide, Oxford University Press, New York, NY, USA, 2nd edition, 1998.

[44] N. Diodato and G. Bellocchi, "MedREM, a rainfall erosivity model for the Mediterranean region," Journal of Hydrology, vol. 387, no. 1-2, pp. 119-127, 2010.
[45] R. Twardosz, "Diurnal variation of precipitation frequency in the warm half of the year according to circulation types in Kraków, South Poland," Theoretical and Applied Climatology, vol. 89, no. 3-4, pp. 229-238, 2007.

[46] P. Panagos, C. Ballabio, P. Borrelli et al., "Rainfall erosivity in Europe," Science of the Total Environment, vol. 511, pp. 801-814, 2015.

[47] N. Diodato and C. Bosco, "Spatial pattern probabilities exceeding critical threshold of annual mean storm-erosivity in EuroMediterranean areas," in Storminess and Environmental Change, pp. 79-99, Springer, Dordrecht, The Netherlands, 2014.

[48] N. Diodato, G. Bellocchi, N. Romano, and G. B. Chirico, "How the aggressiveness of rainfalls in the Mediterranean lands is enhanced by climate change," Climatic Change, vol. 108, no. 3, pp. 591-599, 2011.

[49] O. Nuissier, V. Ducrocq, D. Ricard, C. Lebeaupin, and S. Anquetin, "A numerical study of three catastrophic precipitating events over southern France. I: numerical framework and synoptic ingredients," Quarterly Journal of the Royal Meteorological Society, vol. 134, no. 630, pp. 111-130, 2008.

[50] F. Vinet, "Geographical analysis of damage due to flash floods in southern France: the cases of 12-13 November 1999 and 8-9 September 2002," Applied Geography, vol. 28, no. 4, pp. 323-336, 2008.

[51] M. I. Vousdoukas, R. Verney, F. Dufois et al., "Sediment dynamics in the Bay of Marseille, Gulf of Lions (France): hydrodynamic forcing vs. bed erodibility," Journal of Coastal Research, vol. 27, no. 5, pp. 942-958, 2011.

[52] M. Delmas, O. Cerdan, B. Cheviron, J.-M. Mouchel, and F. Eyrolle, "Sediment export from French rivers to the sea," Earth Surface Processes and Landforms, vol. 37, no. 7, pp. 754-762, 2012.

[53] C. Antonelli, F. Eyrolle, B. Rolland, M. Provansal, and F. Sabatier, "Suspended sediment and 137Cs fluxes during the exceptional December 2003 flood in the Rhone River, southeast France," Geomorphology, vol. 95, no. 3-4, pp. 350-360, 2008.

[54] I. Braud, S. Anquetin, H. Roux et al., "A regional distributed hydrological modelling approach for flash-flood understanding and experimental design," in Proceedings of the 7th EGU General Assembly, pp. 51-54, Vienna, Austria, May 2010.

[55] K. Meusburger, A. Steel, P. Panagos, L. Montanarella, and C. Alewell, "Spatial and temporal variability of rainfall erosivity factor for Switzerland," Hydrology and Earth System Sciences, vol. 16, no. 1, pp. 167-177, 2012.

[56] V. Naipal, C. Reick, J. Pongratz, and K. Van Oost, "Improving the global applicability of the RUSLE model-adjustment of the topographical and rainfall erosivity factors," Geoscientific Model Development Discussions, vol. 8, no. 3, pp. 2991-3035, 2015.

[57] G. J. van Oldenborgh, S. Drijfhout, A. van Ulden et al., "Western Europe is warming much faster than expected," Climate of the Past, vol. 5, no. 1, pp. 1-12, 2009.

[58] R. Romero, J. A. Guijarro, C. Ramis, and S. Alonso, "A 30-year (1964-1993) daily rainfall data base for the spanish mediterranean regions: first exploratory study," International Journal of Climatology, vol. 18, no. 5, pp. 541-560, 1998.

[59] N. Diodato, "Predicting RUSLE (Revised Universal Soil Loss Equation) monthly erosivity index from readily available rainfall data in Mediterranean area," The Environmentalist, vol. 26, no. 1, pp. 63-70, 2006. 

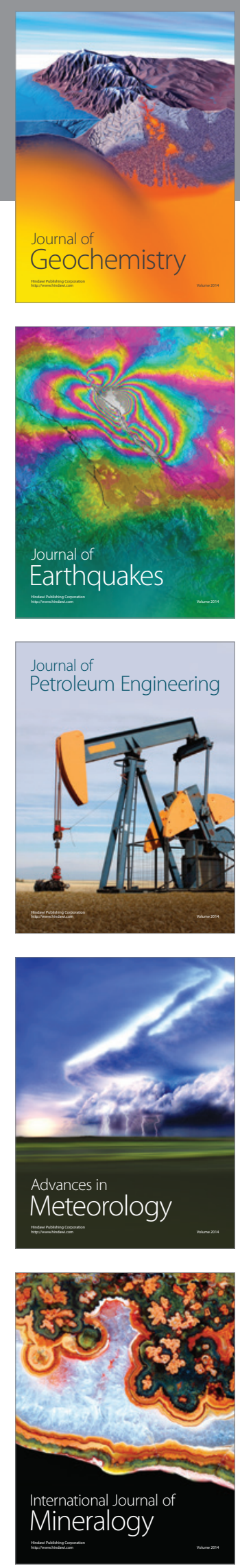
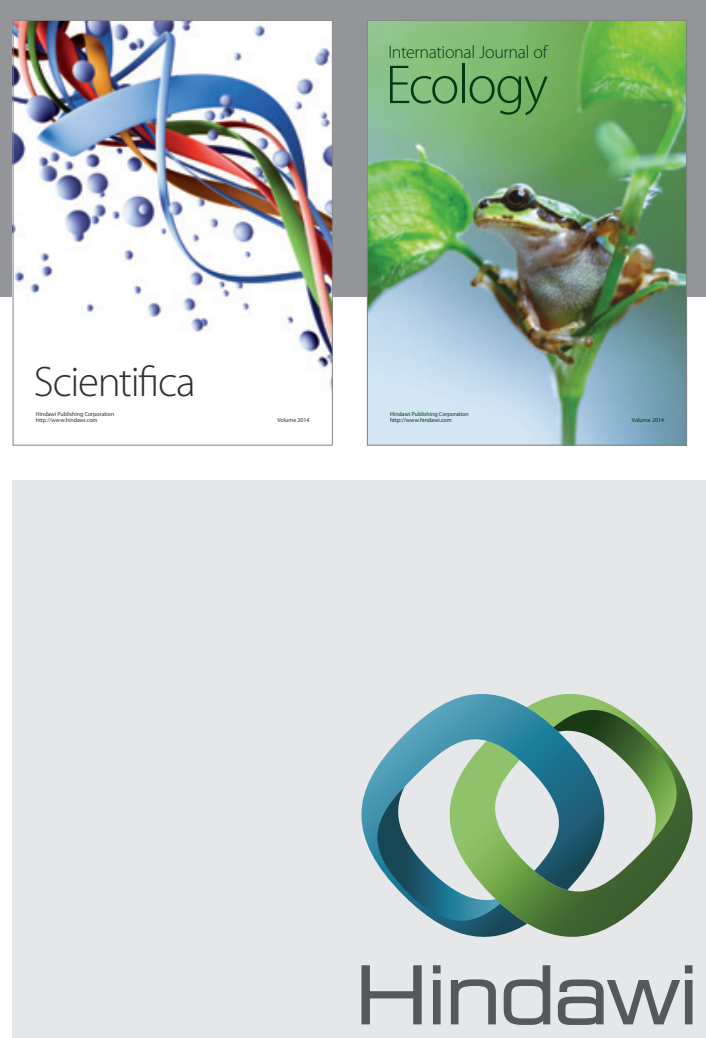

Submit your manuscripts at

http://www.hindawi.com
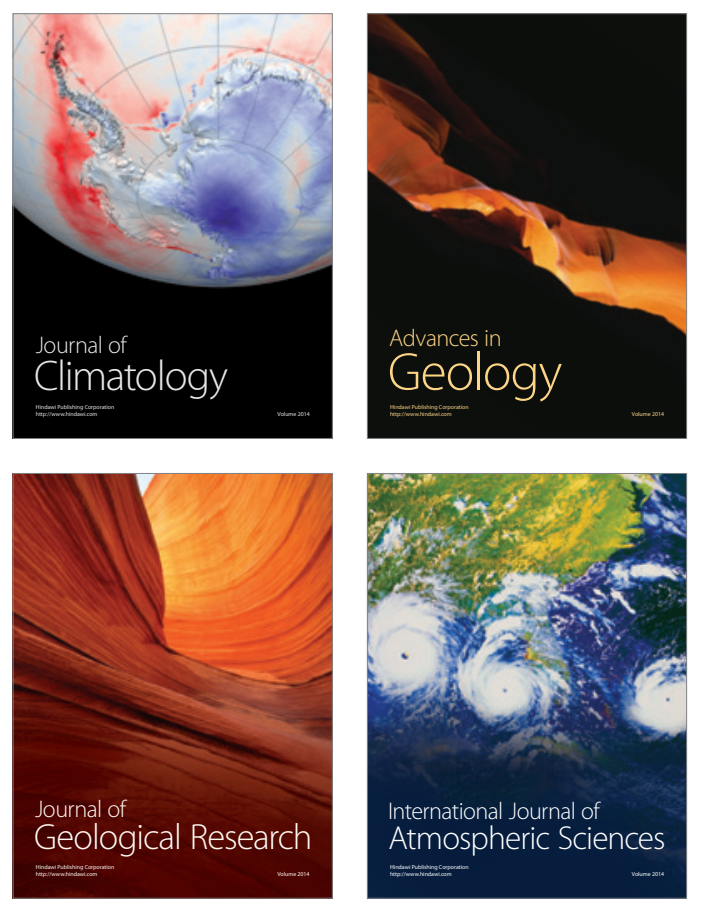

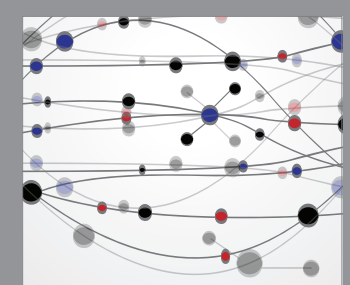

The Scientific

\section{World Journal}
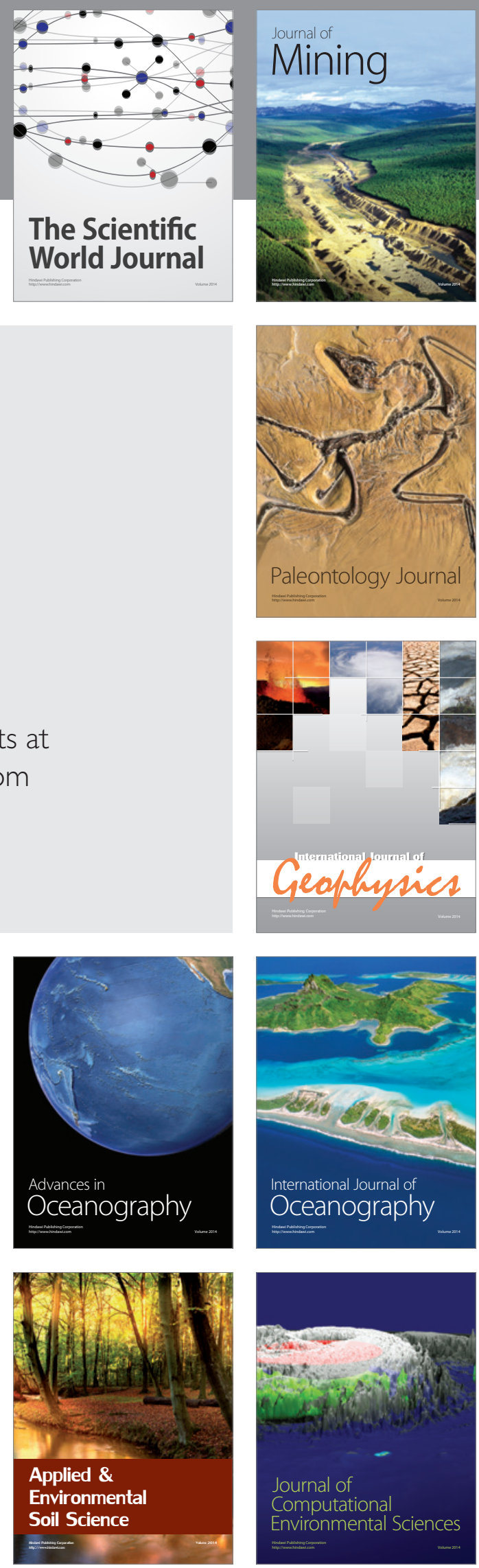